\title{
Methodologies of Economic Measurement and Vulnerability Assessment for Application in Landslide Risk Analysis in a Highway Domain Strip: A Case Study in the Serra Pelada Region (Brazil)
}

\author{
Ellen Felizardo Batista *(D), Larissa De Brum Passini and \\ Alessander Christopher Morales Kormann \\ Graduate Program in Civil Construction Engineering, Federal University of Paraná, Curitiba 81531, Brazil; \\ larissapassini@ufpr.br (L.D.B.P.); alessander@ufpr.br (A.C.M.K.) \\ * Correspondence: ellenfp@ifsp.edu.br; Tel.: +55-(13)-99662-4433
}

Received: 30 July 2019; Accepted: 30 October 2019; Published: 3 November 2019

\begin{abstract}
Landslides are one of the main causes of death caused by disasters in the world. In this study, methodologies to measure landslide costs and to assess vulnerability are presented, with the objective of applying them to landslide risk analyses. The methodologies were applied in a region of Serra do Mar, which is crossed by a highway. The analyses and mappings were implemented in a Geographic Information System (GIS). Through the application of the methodology that considers both direct and indirect costs in the composition of total cost, it was established how much an $\mathrm{m}^{2}$ of a landslide would cost. The composition of direct costs encompassed the damages related to restoration or construction of the highways, infrastructures, unpaved roads, residential and commercial buildings, vegetal cover and agricultural areas. In indirect costs, the economic losses by victims, highway interdiction, and agricultural area profitability were calculated. In the methodology for vulnerability assessment, bodily injuries, structural damages, and functional disturbances resulted from landslides were analyzed. The risk assessment was performed through the junction of the maps of total cost, vulnerability and susceptibility. The results indicate that indirect costs were predominant in cost composition, corresponding to $87 \%$ of total costs, in comparison to $13 \%$ of the direct costs, stressing the importance of considering indirect costs in economic measurement studies. As a result, it is possible to conclude that studying landslide consequences as economic parameters supports the increasing need of performing risk quantitative analyses. It is also prudent to add that these studies help decision makers in projects of disaster risk mitigation strategies, by allowing the identification of regions with greater economic impacts in case of landslide occurrence.
\end{abstract}

Keywords: direct costs; indirect costs; susceptibility; geohazards

\section{Introduction}

Landslides are one of the main accidents caused by disasters in the world [1,2], resulting in social, environmental, and monetary losses [3]. Broad analyses of the consequences are fundamental to reduce harmful effects [4] and for sustainable development of areas that are susceptible to landslides [5].

The landslide risk can be determined by the product between (i) danger, that is, the probability or the susceptibility of a dangerous event to occur, (ii) vulnerability, expressed by the damage factor expected, and (iii) the value (economic measurement) of the exposed elements (human beings, residences, among others.) [6,7]. Identifying risk elements and assessing their relations with the danger constitute the most thorough steps of risk analysis. These relations encompass the landslide potential harmful effect, which is extremely important when defining vulnerability [8]. 
The risk analyses can be performed qualitatively, semi-quantitatively, or quantitatively. Nonetheless, the quantitative assessments allow the identification of regions with greater losses, enabling the possibility to direct the mitigation efforts and increase the risk management effectiveness $[9,10]$.

Thus, the aim of this study was to establish methodologies to (i) measure the economic value of slope landslides and (ii) their vulnerabilities in regions affected by this phenomenon. The losses resulting from landslides can be classified as direct and indirect. The direct losses are related to the costs of replacements, reparation, or maintenance of affected structures $[2,11,12]$. The indirect losses correspond to all other costs related to the interruption of activities, losses of tax revenues, reduction of building values, productivity losses, etc. [2,13].

The identification and quantification of the elements at risk are difficult $[4,7]$. The direct cost estimation can be performed through landslide consequence lists, with monetary correction of costs. However, making such lists is not a trivial task, being usually made only after a great landslide event [14].

Indirect cost values are usually greater than direct cost values [15]. Nevertheless, due to the difficulty of quantification and calculation [16,17], indirect costs are usually ignored in the total cost estimations or, when estimated, usually present values that are lower than the actual ones [18].

The usual absence of information available on the costs generated by the occurrence of landslides, prevent the risk calculation in economic terms $[14,19,20]$. That explains the reduced number of scientific publications that describe approaches that consider economic losses by landslides [17]. Risk analyses based on economic losses are usually performed in local scales [21,22], or along roads and highways [23].

Therefore, in the economic measurement methodology developed in this research, direct and indirect costs were used in the composition of total costs. The composition of direct costs encompassed the damages related to restoration or construction of highways, infrastructures, unpaved roads, residential and commercial buildings, vegetal cover, and agricultural areas.

The composition of indirect costs encompassed economic losses by victims, highway interdictions, and agricultural area profitability. The costs of landslide victims are not usually analyzed in studies related to this theme, even though they are extremely important, because they are greater than direct costs. The vulnerability assessment was performed through a methodology where bodily injuries, structural damages, and functional disturbances of the elements that compose the study region were analyzed.

Risk analysis was obtained through the junction of three maps: the maps of total cost and vulnerability, results of the application of methodologies presented herein; and the map of susceptibility, which can be obtained through several methods widespread in literature [24-27].

The methodologies were applied in the region of Serra Pelada (Brazil), a mountain range characterized by the occurrence of several types of landslides [28-31], which eventually cause roadway traffic jams, property destructions and deaths [29]. Landslides are caused by geological, geotechnical, and geomorphological characteristics of the region, in addition to hydrological discontinuities, caused by the local hot and humid weather. Due to those features, Serra do Mar is a deeply weathered region, with a great propensity to landslide activities [32]. Furthermore, the region is composed of anthropogenic structures along its course, such as urbanization, agriculture, and deforesting, creating countless risk areas [30].

The mapping of economic risk, obtained through the methodologies here presented, allowed the identification of the areas with the highest costs per $\mathrm{m}^{2}$ in a preliminary stage. Thereby helping future decisions in risk mitigation projects, where mitigating actions can be directed to areas of greater interest and in more details. 


\section{Study Area}

The study area covers $13.12 \mathrm{~km}^{2}$, located at Serra do Mar, in the geological region of Serra Pelada, in the city of Barra do Turvo, in São Paulo (SP), a state located in the Southeast region (Figure 1).

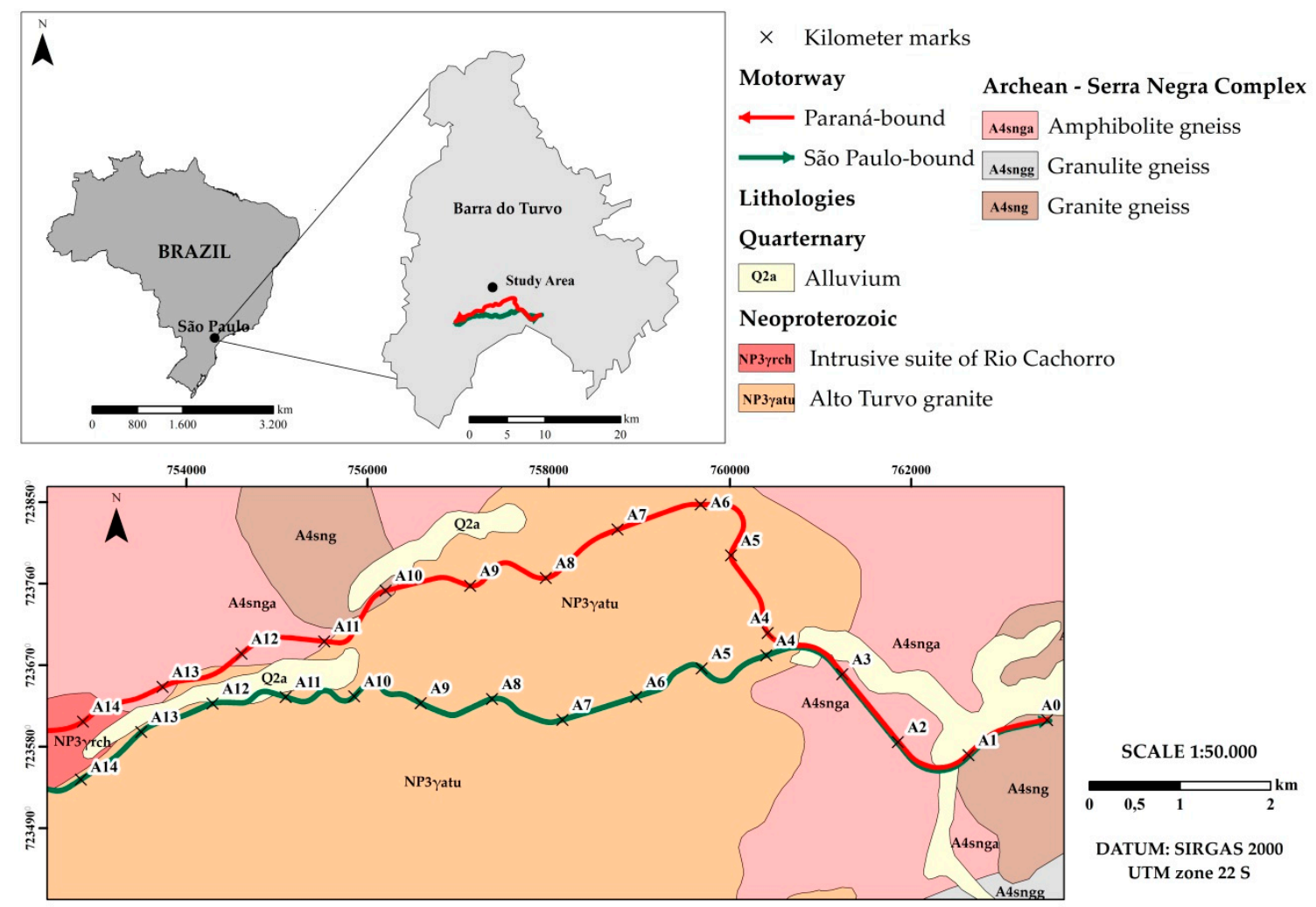

Figure 1. Location and simplified geotechnical-geological map of the study area.

The region is crossed by $15 \mathrm{~km}$ of the highway BR 116/SP, under concession of Régis Bittencourt Highway, a section that plays an essential economic role in Brazilian road network because it is part of the Mercosur route and of the main highway corridor that connects the most important economic poles of the states of São Paulo (SP) and Paraná (PR). It is also located at $180 \mathrm{~km}$ and $347 \mathrm{~km}$ of the Paranaguá (PR) and Santos (SP) ports respectively, which are the ports of greater economic influence in the country [33], presenting an elevated daily volume of users and merchandise transit [34].

Belonging to Ribeira de Iguape e Litoral Sul basin, the local climate can be classified according to Köppen-Geiger as: humid subtropical climate with hot summers, corresponding to $50 \%$ of the area, $45 \%$ is classified as humid subtropical climate with cool summer, and $5 \%$ a humid tropical climate without dry seasons [35]. The annual available precipitation of the region reaches approximately $1400 \mathrm{~mm} /$ year, with well distributed rains, presenting more significant differences between the dry and humid months [36].

Regarding its vegetation, Serra do Mar's escarpment belongs to the domain of Atlantic Forest [37] a woody area with a slope-typical tropical forest, with dense, thick, and heavy trees, $15 \mathrm{~m}$ to $20 \mathrm{~m}$ high and diameters typically varying from $1.0 \mathrm{~m}$ to $1.5 \mathrm{~m}$, therefore protecting the lower forest, making it dark and humid, with stagnant air [38].

About the relief, the region is characterized by steep slopes with gradients varying mainly between $24^{\circ}$ and $37^{\circ}$ [39]. As for its geological features, Serra do Mar is composed of coast lines, mainly formed by Cenozoic sedimentary deposits and high coast lands, constituted by ancient crystalline rocks [36]. It can also be found Tertiary and recent sediments, classified as pediments, colluvium, or alluvium [40]. With a predominantly granite-gneissic constitution, originated by a regional-character 
fail process, the current topographic forms have their origin in the effects caused by mass movements in the decomposition mantle of the region [41].

The Serra Pelada area predominantly has a rock formation called Alto Turvo Granite (Figure 1), whose rocks are constituted by an equigranular, thick, isotropic granite, from pink to light brown, with $5-15 \%$ of widespread mafic minerals, dominated by biotite and hornblende [42]. In some sections, it can be noticed the presence of woods of different sizes and forms, which can endanger the highway in case of landslides. The region is characterized by shallow landslides, usually in the form of translational movements [43].

\section{Methodologies}

The proposed methodologies for economic measurement of landslide and assessment of vulnerability have been implemented in a risk analysis, as the Figure 2 shows. The procedures employed in the economic risk assessment were: (i) Identification of the exposed elements; (ii) gathering local data; (iii) production of the total costs measurement map, considering in its composition both direct and indirect costs; (iv) elaboration of the vulnerability assessment map through the application of loss indexes, ranging from zero (no loss) to one (total loss) [44,45], (v) construction of a susceptibility assessment map expressing the probability of occurring a landslide and (vi) production and validation of economic landslide risk mapping.

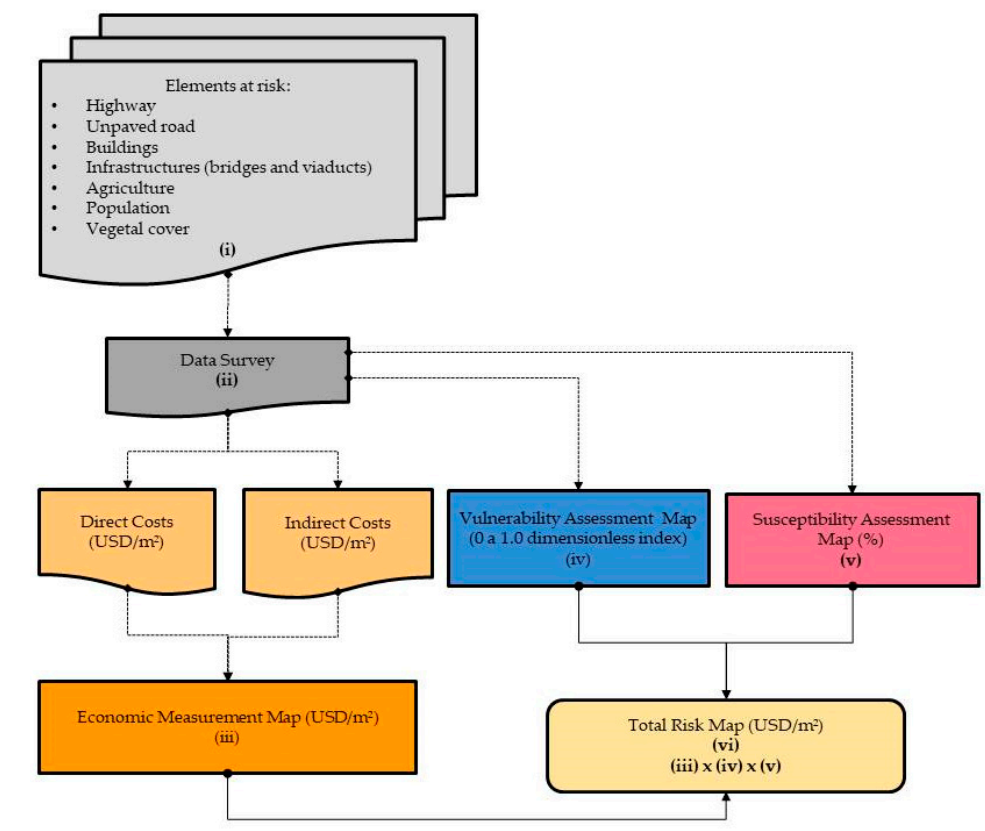

Figure 2. Flow chart of the economic risk assessment based on the application of economic measurement and vulnerability assessment methodologies.

\subsection{Input Data}

The database was built through the digitalization and edition of cartographic information, aerial picture interpretations, and detailed mapping through field visits, and it comprised:

- Land Use Map, designed through aerial images and field visits, with identification of the residences, infrastructures (bridges and viaducts), unpaved roads, agricultural areas, highways, and vegetal cover. One hundred and forty-three buildings were catalogued, and the predominant construction materials were wood and brick, equally. As for the infrastructures, 4 bridges and 3 viaducts were identified, all in reinforced concrete. The agricultural areas are destined to banana plantations. The highway is $7.2 \mathrm{~m}$ wide and corresponds to two lanes of $3.6 \mathrm{~m}$, and the mean traffic of 612 vehicles per hour [46]; 
- Digital Elevation Model (DEM) (Figure 3A), elaborated through a topographic map with $1 \mathrm{~m}$ equidistant level curves, provided by the Régis Bittencourt Highway Concession Holder. A $150 \mathrm{~m}$ domain strip was considered from the highway axle, obtaining the angles, inclination concavities, and elevations;

- Declivity Map, elaborated from the DEM by the ArcGIS 10.5 Slope tool [47] (Figure 3B);

- Simplified Geotechnical-Geological Map, developed to allow the application of the methodologies in economic risk analysis, through the assessment susceptibility. Mean values of geotechnical parameters of residual and colluvial soils were used. Those parameters were obtained through in situ and lab trials, and correlations between direct (probing) and indirect (geophysics) analysis methods in a slope located in Serra Pelada [48].

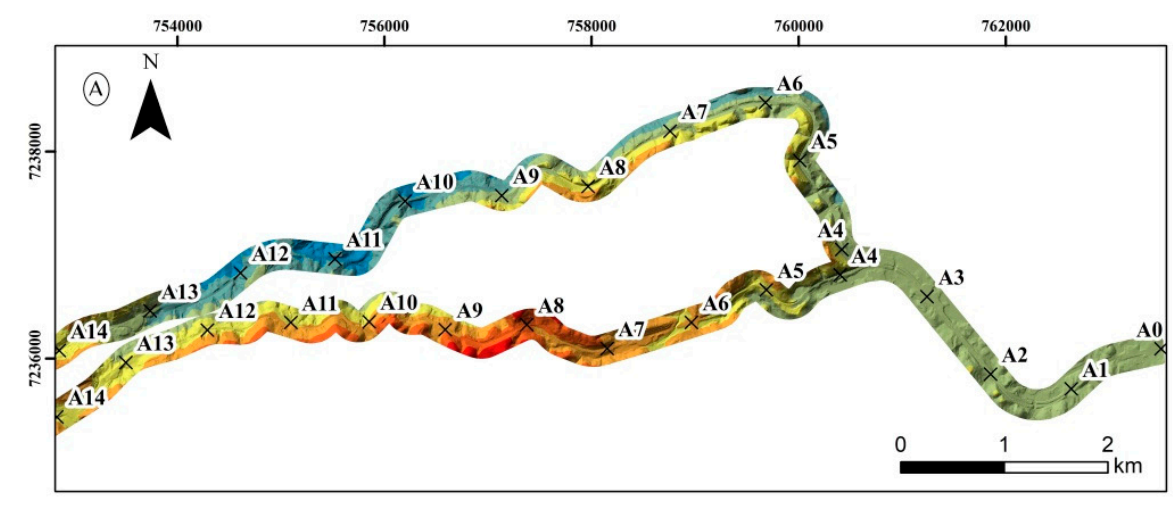

$\times$ Kilometer marks

\section{Elevation (m)}

$874-827$

$827-780$

$780-733$

$733-686$

$686-639$

$639-592$

$592-546$

SCALE 1:50.000

DATUM: SIRGAS 2000 UTM zone $22 \mathrm{~S}$

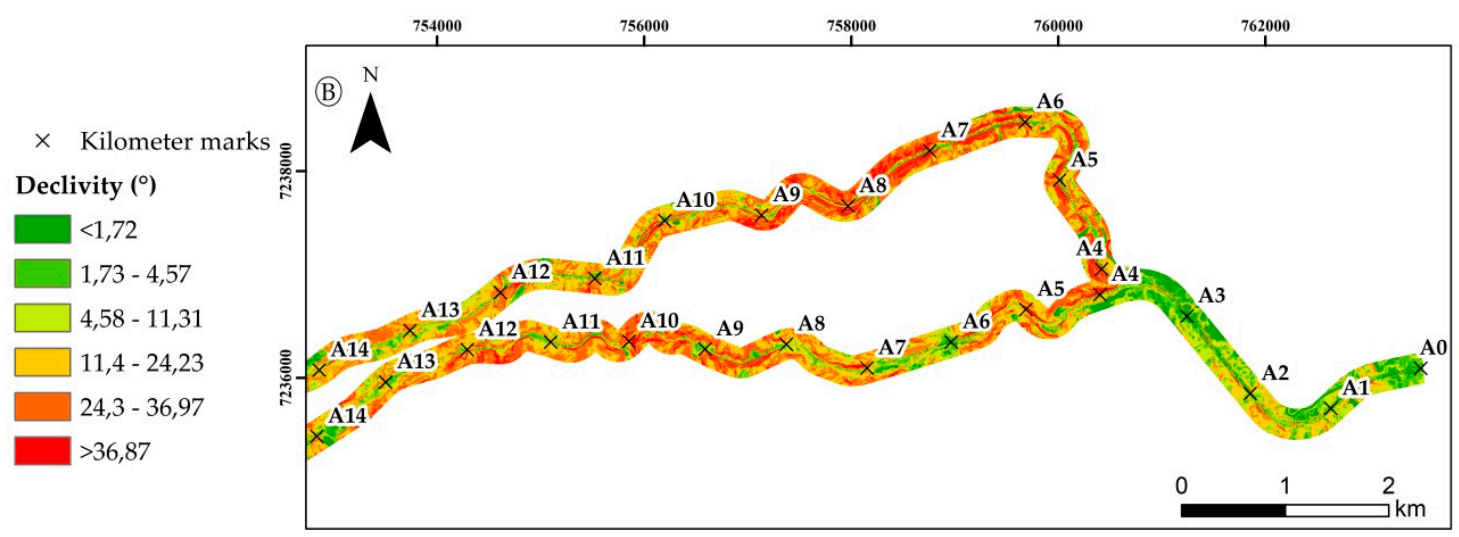

Figure 3. (A) Digital Elevation Model and (B) Declivity.

The maps were digitized and processed in a Geographic Information System (GIS), using ArcGIS 10.5 software [47], with UTM SIRGAS 2000 projection, Zone 22S. The vector polygons of the mapped areas were transformed into raster format, where each pixel represented a geographic region, and the pixel value represented a feature of the region. The dimensions of the pixels were $1 \mathrm{~m} \times 1 \mathrm{~m}$.

\subsection{Economic Measurement}

Cost estimates generated by landslides can be obtained through several different approaches [14]. Due to the absence of lists of landslide consequences in the study region, the proposed methodology for the economic measurement of landslides (Figure 4) was developed simulating a hypothetic landslide situation. 


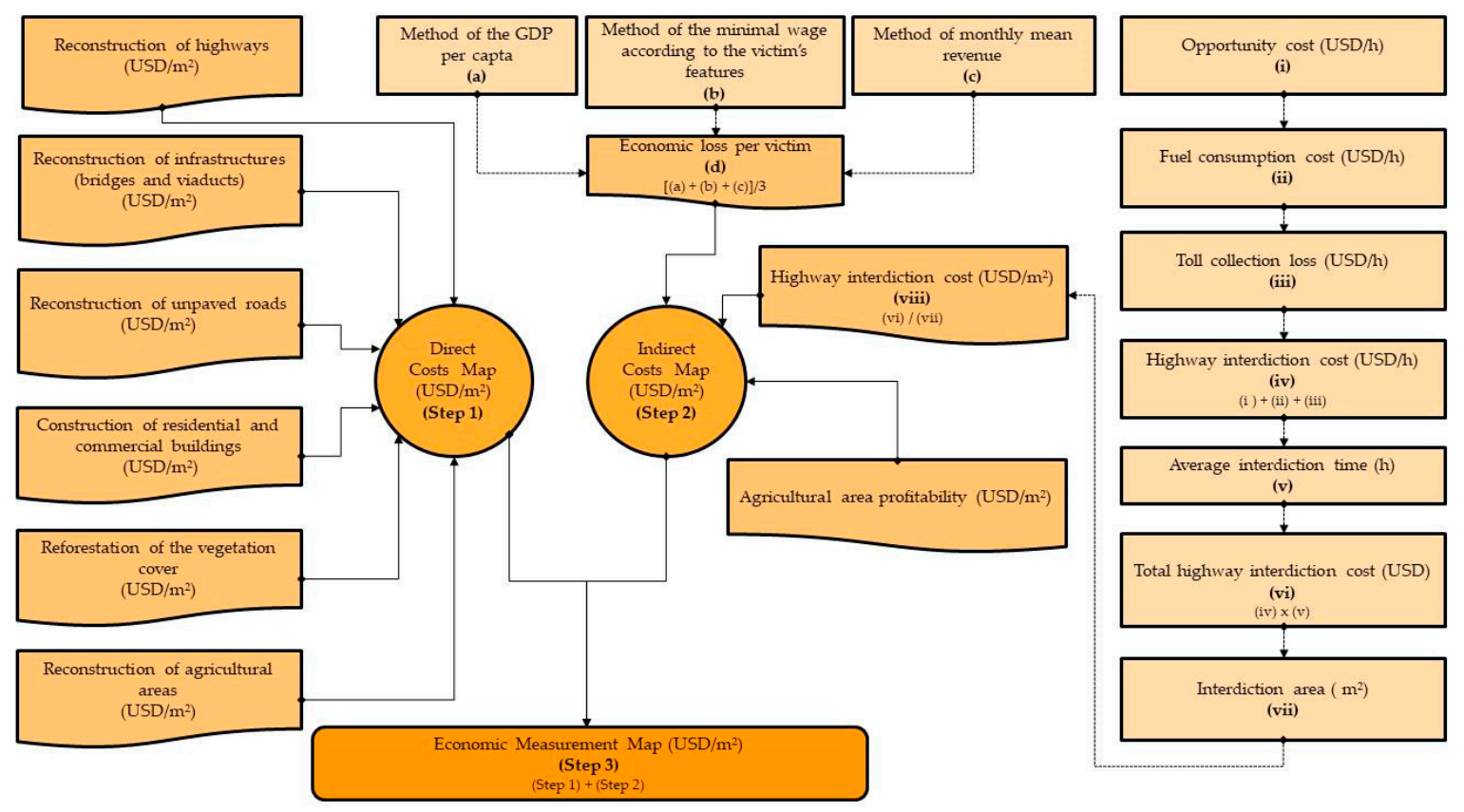

Figure 4. Flowchart of the methodology of landslide economic measurement.

The following steps structured the methodology for economic measurement:

Step $1-$ comprising the steps of determining direct costs per $\mathrm{m}^{2}$ for highway reconstruction, reconstruction of infrastructures (bridges and viaducts), reconstruction of unpaved roads, construction of buildings, reforestation of the vegetation cover and cultivation of agricultural areas;

Step 2-formed by estimates of indirect costs per $\mathrm{m}^{2}$, considering in its composition the economic losses with victims, highway interdictions and losses of profitability of agricultural areas;

Step 3-sum of direct and indirect cost maps to get economic measurement map (total cost per $\mathrm{m}^{2}$ ).

\subsubsection{Direct Costs}

The composition of direct costs encompassed the damages related to the reconstruction of highways, infrastructures, unpaved roads, residential and commercial buildings, vegetal cover, and agricultural areas.

The landslides on slopes, due to their magnitude, can result in total or partial destruction of highways and infrastructures that cross such slopes [17]. The costs can be obtained through budgets based on quantitative estimates of services and materials of an executive project [49]. The huge variability of events and consequences resulting from the movement of slopes directly reflect in the amount of possible solutions for the project. Therefore, the average managerial costs were employed in the estimation presented here, according to the publication of the National Department of Transport Infrastructure [50], for the construction of the highway and of infrastructures existing in the study area.

For the costs related to the reconstruction of unpaved roads, through land regularization and bulging, and gravel transportation, the values were defined based on the unpaved roads maintenance project developed by the Institute of Technical Assistance and Rural Extension of Paraná [51] and with the historical inflation rates available the price could be corrected and updated.

The value assigned to the construction of the buildings was based on the Basic Unitary Cost of Construction (BUC) published by the Brazilian Chamber of the Construction Industry [52], whose composition encompasses the materials, labor, managerial expenses, and equipment.

Landslides can also result in vegetation cover degradation, which makes these areas lose their productive capability, since the fertile layer is taken away or covered [53]. The Degraded Area Recovery Plans (DARP) presented mean values between USD 132.00 to USD 3900.00 by recovered hectare [54,55]. The value variability is caused by the different recovery techniques employed, by the use of seeds 
instead of seedlings, and by the regional variation of some costs, such as professional wages, tools, fuel, etc.

The direct cost of agricultural areas corresponded to the cultivation of the banana crops in the study section [56], for a space of $3 \mathrm{~m} \times 3 \mathrm{~m}$ and density of 1.111 plants/ha [57].

\subsubsection{Indirect Costs}

In indirect costs, we calculated the economic losses by victims, highway interdictions, and agricultural area profitability [15]. Landslide risk analyses based on costs usually do not consider human productivity losses caused by injuries or death [14]. Nevertheless, since the study region presents a great concentration of people in places susceptible to landslides, these losses were included. The indirect cost by fatal victims (Figure 4) in a landslide situation was established through the Value of Statistical Life (VSL) analysis, which is adopted in studies of public project assessment with the purpose of avoiding death occurrence, and refers to the amount of resources that the society intends to invest to save the life of a random person [58-60]. The human-capital (HC) method was employed, which corresponds to the revenue lost due to death [60].

Based on the Gross Domestic Product (GDP) and on Brazilian population size [61] the Value of Statistical Life (VSL) was determined, from the ratio $\partial=$ (VSL/GDP per capita), with life expectancy intervals $(\partial)$ varying from 60 to 80 years, based on a statistical study made in 22 countries [62].

The studies that present estimates of the VSL using the HC methodology adopted the revenue per capita of the country as the mean revenue that would be generated by a deadly injured person. On the other hand, this alternative has several problems because of the diversity of revenue values of the people who, due to landslide accidents, died prematurely [60]. Therefore, the VSL was also estimated due to the average number of minimal wages divided by gender and academic formation of the victim [63]. The values were multiplied by 1.9 [60] to consider the work charges and indirect compensations.

Trying to obtain greater levels of value that can offer a more precise estimative, local newspapers and magazines were studied, trying to find landslide event registrations in highways with fatal victims and their respective ages. We noticed that the mean age of the victims was 25 years. According to the Brazilian mortality table the life expectancy for individuals that are exactly 25 years old is 77.9 years [64]. Through the Brazilian monthly revenue, per capita, from 2015 to 2018 [61], whose annual mean variation was of $1.88 \%$, we calculated the estimated value of production loss for the year of 2071, established by the victims life expectancy minus their mean age. The final cost of the economic loss with victims was established through the mean between the values of the minimal wage according to the GDP per capita (based on the characteristics of the victims) and by the monthly mean revenue.

The composition of the highway interdiction cost was initially established by the sum of the following costs: (i) Costs of opportunity related to users' lost time during the interruption of the highway, (ii) costs of the fuel consumption during the interruption and (iii) costs of toll collection along the way.

The opportunity cost (i) consists in a theoretical value and it is related to the alternative use of the time employed by the highway users during the interruption [65] and this value was obtained through the multiplication of EAP (Economically Active Population) hour value by the average hourly traffic of the highway. Initially, it was calculated the value of the hour spent by the Brazilians, through the division of the GDP per capita of the occupied EAP [61], by the annual worked hours, considering 253 working days in the year and 8 daily work hours. Then, it was possible to obtain the number of users using the highway, which were 1404 users per hour. This value was obtained through the multiplication of the occupation rates of 25 passengers by bus and 1.8 people by car and truck [66] and the hourly numbers of 599 cars and trucks and 13 buses registered by the National Research of Traffic (NRT) made by the Brazilian Army in 2016 in Station 66 of BR-116.

During the interruption of a highway in a landslide situation, the users tend to remain inside their vehicles and keep them running, for safety reasons and to avoid thermal issues. Despite the variability of the magnitude and consequences of a landslide event, based on records of the average highway 
interdiction time for these occasions, it is possible to estimate the cost of fuel consumption (ii) in the composition of indirect costs.

Due to the absence of national data on fuel consumption, we employed an American reference [67], because, although the American vehicles follow different patterns from the Brazilian ones, such difference is irrelevant because the American gasoline presents a better performance due to its elevated octane level. As for the vehicles running on diesel oil, there is a similarity in both countries, which makes differences irrelevant.

The fuel consumption cost, presented in Equation (1) [67], was composed of the cost to keep the engines running when the vehicle is stationary, and the cost of the vehicle in the period it begins to slow down, due to the need of stopping the car, until the moment in which the vehicle regains its speed.

$$
\mathrm{CC}=\mathrm{c} \times\left(\mathrm{K} \prime \times \mathrm{A}+\mathrm{K}^{\prime \prime} \times \mathrm{B}\right)
$$

where CC is the fuel consumption cost per hour; $c$ is the fuel cost (USD/l), whose value for gasoline and diesel oil was USD 1.16/1 and USD 0.98/1 respectively [68]; $\mathrm{K}$ ' is the experimentally determined correction factor, considering the expenditures with lubricant oil, maintenance, and vehicle depreciation, which is 1.36 for automobiles and 3.07 for commercial vehicles [67]; A is the consumption of the vehicles when they are stationary $(1 / \mathrm{h})$, which is 1.40 for gasoline and 1.51 for diesel oil [67]; $\mathrm{K}^{\prime \prime}$ is the experimentally determined correction factor, considering the expenditures with lubricant oil, maintenance, and vehicle depreciation, corresponding to 1.5 for automobiles and 3.5 for commercial vehicles [67]; $B$ is the vehicle consumption (l/cycle) according to the speed in $\mathrm{km} / \mathrm{h}$ of $60 \mathrm{~km} / \mathrm{h}$, the minimal speed in a Brazilian highway, is 0.041 for automobiles and 0.251 for commercial vehicles [67].

By multiplying the hourly flow of automobiles and commercial vehicles (buses and trucks) on the highway for the cost of hourly fuel consumption, it was possible to measure the total fuel cost per hour on the highway.

For the costs related to toll collection, we adopted the time value by direction (São Paulo or Paraná) published in the Complete Annual Financial Statement report of the Régis Bittencourt Highway [69].

Thus, the highway interdiction costs were multiplied by the average time of interdiction of the highway in landslides situations, and then it was divided between the interdicted areas, resulting in the cost of interdiction in USD $/ \mathrm{m}^{2}$ (Figure 4). The banana plantation profitability loss was classified as an indirect cost and its value was established according to the profitability cost table for one hectare of bananas [57], considering a lifespan of 6 years with the productivity of 15 tons per year.

After establishing the costs, they were applied in their respective regions in the land use map, obtaining the maps of direct (Step 1) and indirect costs (Step 2). The land use map polygons were converted into rasters $[70,71]$ to enable the application of map algebra tools. Through the sum of direct and indirect cost maps, the economic measurement map was obtained (Step 3).

\subsection{Vulnerability Analysis}

The methodology proposed for vulnerability analysis (Figure 5) is characterized by the attribution of loss indexes to sets of exposed elements [72]. That is, all elements threatened by a landslide phenomenon, such as inhabitants, buildings, infrastructures, and activities [45,73]. 


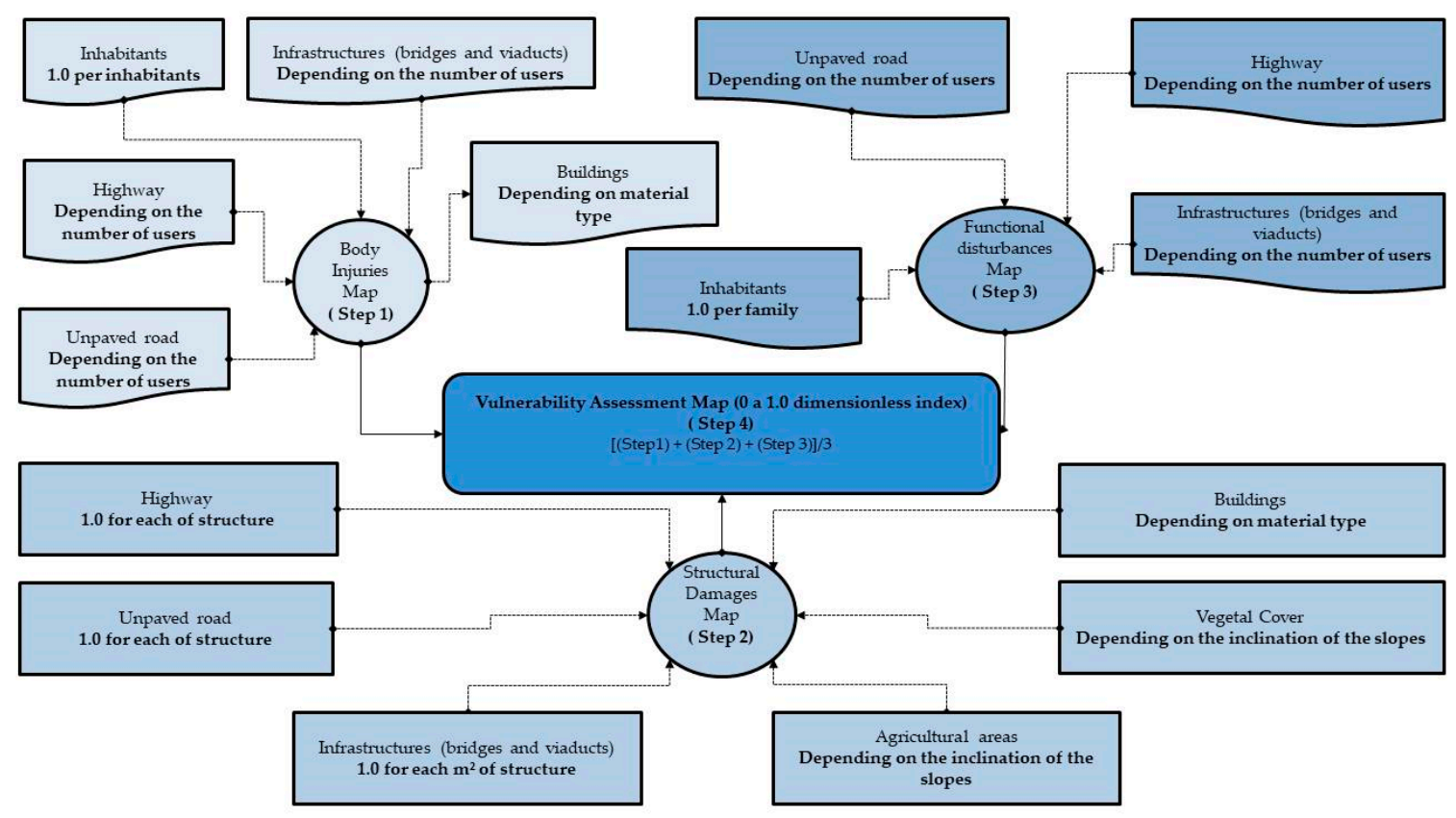

Figure 5. Flowchart of the methodology of vulnerability assessment.

The following steps structured the methodology for assessing total vulnerability:

Step 1-body injuries analysis, comprising a map based on a survey of the number of inhabitants and people using the highway, the infrastructures and unpaved roads, and type of material (masonry and wood) of the buildings;

Step 2-structural damages analysis, comprising a map based on the presence of highways, unpaved roads and infrastructures (in $\mathrm{m}^{2}$ of structure), slopes declivity associated with agricultural areas and vegetation cover, and type of building material (masonry and wood);

Step 3-functional disturbances analysis, based on a map achieved by verifying the number of people using the highways, unpaved roads and the number of families relocated;

Step 4-assessment of total vulnerability got through the average of the maps of body injuries, structural damages and functional disturbances.

Based on the definition of exposed elements, maps were drawn to assess body injuries (Step 1), structural damages (Step 2) and functional disturbances (Step 3), to which these elements can be vulnerable. Then, indexes of dimensionless losses were applied, varying from 0.0 to 1.0 to each set of exposed elements, as the value 1.0 represented the most vulnerable class $[8,22,74]$. For the elements with absence of local data we employed values of indexes found in the literature. For all other cases, the index values were estimated through the number of inhabitants, highway users, unpaved roads, and slopes declivity.

For the body injury map (Step 1), the number of inhabitants in the study region was initially determined by multiplying 143 buildings by an average of 3.3 inhabitants per building [75], totaling 472 inhabitants. The number of inhabitants was used in the analysis of the body injuries, because the probability of having victims increases alongside with it. The inhabitants' vulnerability encompasses several aspects, such as age linked to mobility, landslide speed, spatial location, type of material (rock or soil), etc. Therefore, to each inhabitant it was given the loss index of 1.0, indicating very serious damages, considering the worse situation [76,77].

The number of people that use the highway, unpaved roads, and infrastructures was employed in the body injuries analysis, because the higher the traffic density is, the greater the landslide-caused damages will be. In average, the daily volume of the highway users corresponds to 33,696 people [46]. For unpaved roads, we considered the amount of 472 inhabitants in the study region, therefore 
establishing the loss index equal to 1.0 for highways, due to its heavier traffic, and the proportional index of 0.01 for unpaved roads (Table 1 ).

Table 1. Summary table of the indexes used according to the type of material, number of users and slope relief classification.

\begin{tabular}{ccc}
\hline Elements & Typology & Indexes \\
\hline \multirow{2}{*}{ Building } & Brick masonry & 0.50 \\
& Wooden & 1.00 \\
\hline \multirow{2}{*}{ Roads } & Highway & 1.00 \\
& Unpaved road & 0.01 \\
\hline \multirow{3}{*}{ Slope Relief classification } & $0-3 \%$ & 0.17 \\
& $3-8 \%$ & 0.34 \\
& $8-20 \%$ & 0.51 \\
& $20-45 \%$ & 0.68 \\
& $45-75 \%$ & 0.85 \\
& $>75 \%$ & 1.00 \\
\hline
\end{tabular}

For buildings, the vulnerability depends on components such as: building technique, construction material, conservation condition, and number of floors. Wooden and metallic structures present greater vulnerability in comparison to reinforced concrete constructions [78].

In this way, the type of material was used as a reference for the attribution of loss indexes, as a function of the probability of having people inside the buildings during the occurrence of a landslide event. We based the applied indexes on the structural resistance of the materials, using values of 0.5 for the brickwork and 1.0 for wood [78] (Table 1).

In the structural damages map (Step 2) the vulnerabilities of highways, unpaved roads and infrastructures were analyzed by assigning the index of 1.0 for each structure, considering a critical situation with very serious damages [77].The inclination of the slopes were employed in the analysis of structural damages associated with agricultural areas and vegetation cover, considering that the greater the slope inclination level is, the greater the landslide vulnerability will be. The indexes were proportionally established for the six relief classification classes [39], according to the increase of the inclination percentage (Table 1).

For the buildings, in the assessment of the structural damages in landslide situations, the index of 0.5 was assigned for brickwork and 1.0 for wood [78] (Table 1). For the functional disturbances map (Step 3), as well as in the body injury map, the numbers of users using the highway, infrastructures and unpaved roads were used to establish the vulnerability index of these elements, obtaining values of 1.0 for the highway and infrastructures, due to its heavier traffic, and the proportional index of 0.01 for unpaved roads (Table 1).

The number of families that should be relocated in case of landslides was used in the functional disturbances analysis with the attribution of the loss index of 1.0 for each family.

The total vulnerability (Step 4) was mapped through the mean of the bodily injuries, structural damages, and functional disturbances maps. The tool used to get the results was the raster calculator, from spatial analyst tools, in the map algebra tab, in ArcGIS [47] The selection of a simple arithmetic mean was made to obtain vulnerability through the influence of all the analysis previously performed.

\subsection{Susceptibility Analysis}

In order to apply the methodologies for economic measurement of landslides and vulnerability assessment in a risk analysis, the susceptibility assessment was performed, so that the product between the total cost, vulnerability and probability maps could be obtained. 
In the susceptibility analysis, from the data of the Digital Elevation Model (DEM) and the average geotechnical parameters of the soil and by deterministic means, using the Limit Equilibrium Method (LEM) for infinite slopes, the Safety Factor (Fs) could be calculated.

Since a great part of the landslides of the study area are translational and superficial, the stability analysis using the infinite slope method is adequate because it is a large slope with a very thin soil covering layer, that can easily move $[79,80]$.

The Fs can be calculated using an equilibrium equation. It is the ratio between the Mobilizing (M) forces and the Resistant forces (R). Several methods can be used in the development of this equation with their respective hypotheses. In the present study, we used the following Equation (2) [81-83], where the characteristics of the slopes, its soil, its hydrological features and the actions caused by the wind were considered [84].

$$
F_{s}=\frac{C_{s}+\left[\left(\gamma_{n a t}-W \times \gamma_{a}\right) \times h x \cos i+\sigma_{a} x \cos i\right] \times \tan \varphi}{\left(h \times \gamma_{n a t}+\sigma_{a}\right) \times \sin i+\sigma_{v e}}
$$

where $F_{s}$ is the safety factor; $C_{s}$ is the cohesion intercept, $\varphi$ is the friction angle, and $\gamma_{\text {nat }}$ is the natural specific weight, each one with the respective value of $10 \mathrm{kPa}, 25^{\circ}$ and $17 \mathrm{kN} / \mathrm{m}^{3}$, respectively [48]; $\gamma_{\mathrm{a}}$ refers to the water specific weight of $10 \mathrm{kN} / \mathrm{m}^{3} ; \sigma_{\mathrm{a}}$ is the pressure applied by the weight of the trees for the region of Serra do Mar of $3 \mathrm{kPa}$ [85]; $\sigma_{\mathrm{ve}}$ refers to the pressure exerted by the wind on the treetops of $1 \mathrm{kPa}$ [83]; $\mathrm{h}$ is the soil layer thickness of $2 \mathrm{~m}$, since it was proven by physical and morphological characterizations that the landslides of the translational types occurring in Serra do Mar present low depth layers [86]; i represent the inclination angles of the slope with values corresponding to the rasters obtained in the mapping of the declivity; $\mathrm{W}$ refers to the soil saturation with the value equal to 1.0 , representing the worse condition, which would be a $100 \%$ saturated soil.

The $\mathrm{F}_{\mathrm{S}}$ modeling was generated by applying the Equation (2) with the raster calculator tool in the software ArcGIS [47]. The $\mathrm{F}_{\mathrm{s}}$ map generated was classified in 4 intervals, being (i) inferior to 1.0, representing extremely high susceptibility, (ii) from 1.0 to 1.5 , for high susceptibility, (iii) from 1.5 to 2.0 for moderate susceptibility, and (iv) above 2.0, for low susceptibility [87].

Then, the landslide occurrence probability was calculated through the $F_{\mathrm{s}}$ modeling, where the determining values of the Resistant (R) and Mobilizing (M) forces exert influence. The estimations of these forces show that there is a variance related to them. Consequently, a Safety Margin (SM) was established, where $S M=(R-M)$. The $S M$ presents a random variation and a probability distribution. The rupture probability is equal to the probability of $\mathrm{SM}$ being lower than 0 (zero). $\mathrm{F}_{\mathrm{S}}$ is function of a set of randomized variables. Therefore, we consider the probability distribution of $\mathrm{F}_{\mathrm{s}}$ as close to a normal distribution, that is, the probability distributions of $\mathrm{F}_{\mathrm{S}}$ and $\mathrm{SM}$ are similar. The probability distribution measurement can be expressed by the Equation (3):

$$
\beta=\frac{\left(\mathrm{F}_{\mathrm{s}}-1.0\right)}{\sigma_{\mathrm{F}_{\mathrm{s}}}}
$$

where $\beta$ is the reliability index; $F_{s}$ is the safety factor; 1.0 is the mean employed for the normal curve because the modeling was made based on $\mathrm{F}_{\mathrm{S}}$, where values over 1.0 (one) represent stable slopes and values under 1.0 represent slopes susceptible to landslides; and $\sigma_{\mathrm{F}_{\mathrm{S}}}$ is the standard deviation of the factor of safety [84].

From the standard deviation of $F_{s}$, obtained through the variation of values represented in each pixel of the $F_{s}$ modeling, the values of $\beta$ were calculated by applying the Equation (3) with the raster calculator tool in the software ArcGIS [47]. The values of $\beta$ ranged from 0 to 3.62467. The values of each pixel of the $\beta$ modeling were applied to a normal distribution table, which represents the area implied by the reduced normal curve [88], equivalent to the value of $\beta$. Subsequently, the values of $\beta$ were then reclassified, through the reclassify tool in ArcGIS [47], as a landslide probability spatial model. Intervals of 5 in $5 \%$ were attributed to the probability map for a better visualization. 


\section{Results and Discussion}

This section presents the results and analyses generated from the application of economic measurement methodologies and vulnerability assessment in a landslide economic risk analysis through the product between total cost, vulnerability and susceptibility maps.

\subsection{Economic Measurement Assessment}

Through the economic measurement methodology here presented, the final costs were obtained and used in landslides risk analysis. Those costs were updated through the Consumer Price Index (CPI) of January 2019, for monetary references prior to 2019.

\subsubsection{Direct Costs}

In direct costs composition, the following mean values were adopted for the exposed element damages: (i) USD $232.45 / \mathrm{m}^{2}$ for constructing of a double-lane highway, with $7.2 \mathrm{~m}$ wide lanes and a roadside $2.5 \mathrm{~m}$ wide added to the cost of the project. [50]; (ii) USD $1046.57 / \mathrm{m}^{2}$ for the reinforced concrete infrastructures [50]; (iii) USD $0.27 / \mathrm{m}^{2}$ for reconstructing unpaved roads [51]; (iv) USD $357.35 / \mathrm{m}^{2}$ for the buildings [52]; (v) USD $0.54 / \mathrm{m}^{2}$ for reforesting the vegetal cover with structural and functional characteristics that are similar to the original forests [55]; and (vi) USD $1.85 / \mathrm{m}^{2}$ for the banana crop cultivation [57] for a productive lifespan of six years on the orchard [89]. The costs obtained were applied in land use map, obtaining the direct costs map, due to landslides in the region of interest.

\subsubsection{Indirect Costs}

As for indirect costs, for the economic loss per victim, it was established the value of USD 630 thousand, obtained through the mean between the GDP per capita which was USD 540 thousand, the minimal wage which was USD 710 thousand, and the monthly mean revenue of USD 630 thousand.

Some authors $[59,90]$ mention how difficult it is to quantify the costs of injuries and life losses and the discrepancy of the estimated values, which vary from USD 1 to 10 million dollars. The amount of USD 3 million dollars, above the estimated, is usually employed to attribute life expectancy values in developed countries [90]. Nevertheless, it must be stressed that Brazil is a developing country, with different economic features in comparison with developed ones.

The highway interdiction cost due to landslide issues was of USD $0.78 / \mathrm{m}^{2}$ (Table 2). The value of an 8-h period of highway interdiction was based on experiences with local landslide events.

Table 2. Composition of highway interdiction cost.

\begin{tabular}{cccccc}
\hline $\begin{array}{c}\text { Composition of the Costs of Interdiction } \\
\text { (USD/h) }\end{array}$ & $\begin{array}{c}\text { Duration of } \\
\text { Interdiction } \\
\mathbf{( h )}\end{array}$ & $\begin{array}{c}\text { Cost of } \\
\text { Interdiction by } \\
\text { Landslide } \\
\text { (USD) }\end{array}$ & $\begin{array}{c}\text { Total } \\
\text { Highway } \\
\text { Area }\left(\mathbf{m}^{2}\right)\end{array}$ & $\begin{array}{c}\text { Cost of } \\
\text { Interdiction } \\
\left.\mathbf{( U S D} / \mathbf{m}^{2}\right)\end{array}$ \\
\hline $\begin{array}{c}\text { Opportunity cost } \\
\begin{array}{c}\text { Cost with fuel consumption } \\
\text { Loss of toll collection }\end{array}\end{array}$ & $\begin{array}{c}11,718.37 \\
2618.59\end{array}$ & 8 & $209,795.50$ & $268,392.48$ & 0.78 \\
\hline
\end{tabular}

The cost attributed to the loss in the banana plantation was of USD $0.50 / \mathrm{m}^{2}$ [57] for a 6-year lifespan. The calculated costs were applied in land use map, obtaining the indirect costs map, due to landslides in the region of study.

\subsubsection{Total Costs}

Through the sum of the direct and indirect maps, we made a total cost map (Figure 6). Detailing the kilometer marks A11-A12 (towards Paraná) allows a better visualization of the cost distribution and represents the stretch with the greatest quantity of elements. This detail will be presented in all subsequent maps, in order to allow a comparison between the applied methodologies. 


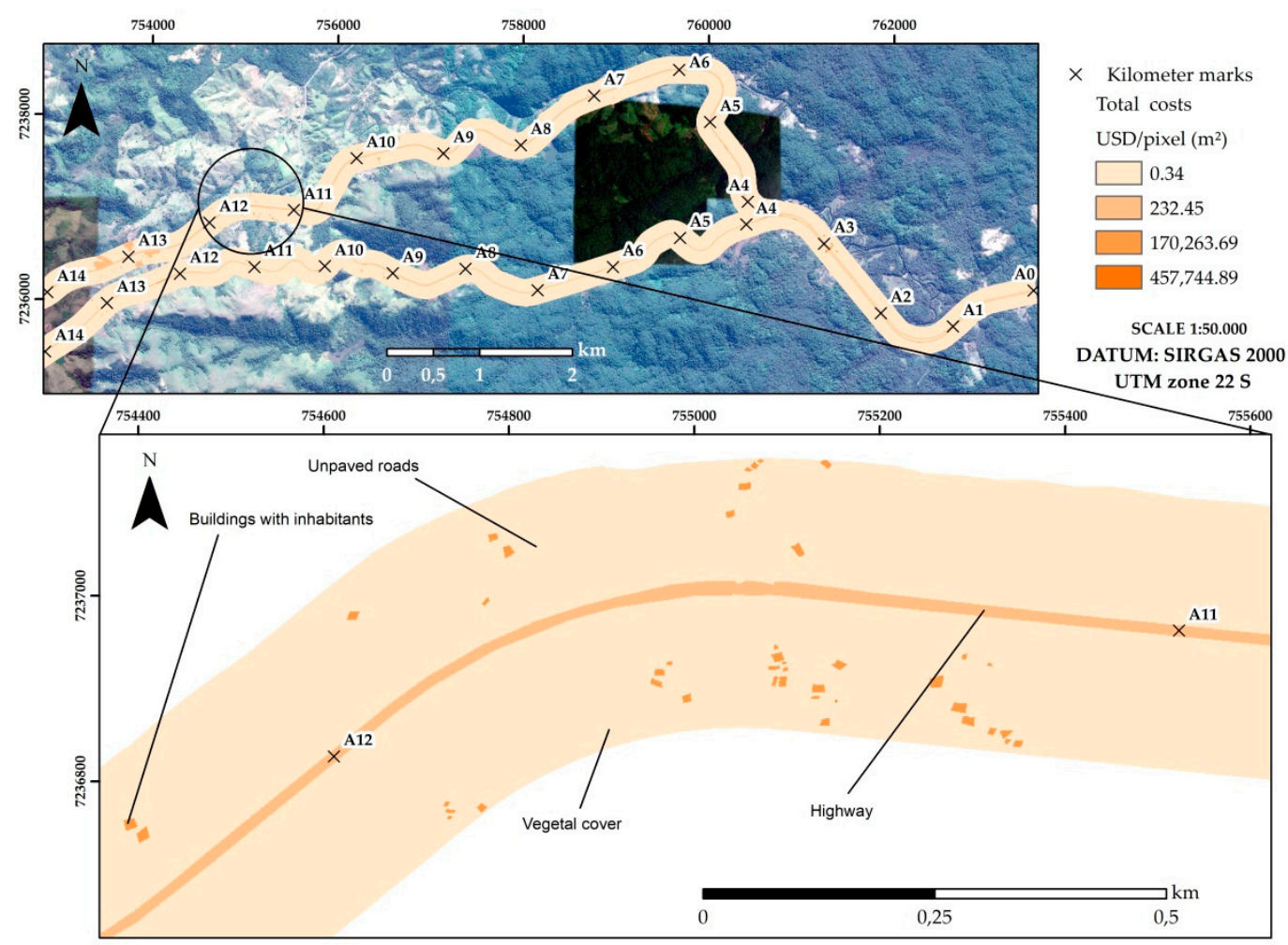

Figure 6. Total costs map $\left(\mathrm{USD} / \mathrm{m}^{2}\right)$, with identifications of the areas with the highest economic value.

The total costs are represented in an ascending color scale according to their values and divided into four intervals to allow a better visualization of the cost distribution.

In dark orange, we highlight the buildings with presence of inhabitants, as being the elements with greater economic appreciation, presenting a maximum cost per pixel of USD $457,744.89 / \mathrm{m}^{2}$. In light orange, we highlight vegetation cover and unpaved roads, as being the elements with lower economic appreciation, presenting minimum cost per pixel of USD $0.34 / \mathrm{m}^{2}$.

Considering the total area of interest and regarding direct costs, the highways, the infrastructures, and the buildings were the exposed elements that presented greater appreciation, exhibiting final cost values of approximately USD 32 million, USD 6 million and USD 4.5 million, respectively. As for the total indirect costs, the greater value was the cost with victims of approximately USD 306 million, followed by the highway interdiction cost of USD 53 thousand and the banana plantation profitability loss of USD 18 thousand (Table 3).

Table 3. Summary table of total direct and indirect costs of the study area.

\begin{tabular}{ccc}
\hline Elements Exposed & Direct Costs (USD) & Indirect Costs (USD) \\
\hline Highway & $31,895,716.85$ & - \\
Infrastructures & $5,785,168.14$ & - \\
Buildings & $4,522,820.29$ & - \\
Vegetal cover & $3,633,858.58$ & - \\
Banana plantation & $67,508.01$ & $18,307.28$ \\
Unpaved road & $14,131.57$ & - \\
Victims & - & $306,054,263.09$ \\
Highway interdiction & - & $53,852.16$ \\
\hline
\end{tabular}

In the economic measurement, $86.96 \%$ of the total cost is represented by indirect costs and $13.04 \%$ by direct costs. These percentages were obtained considering the victims cost as indirect. In literature, the cost estimation studies usually do not consider the victim's economic losses [14]. In this situation 
(without considering the victims), for the study area, the indirect costs were of $0.16 \%$ and the direct costs of $99.84 \%$, which would make of this evaluation underestimated.

In Brazil, an assessment report of the economic losses generated after a landslide disaster caused by heavy rains that struck the Mountain Range Region of Rio de Janeiro, in 11 and 12 January 2011 [91], presented a total cost composition of $46 \%$ of direct costs and $54 \%$ of indirect costs. In other words, the indirect costs were superior to the direct costs, and the study did not measure the economic loss with victims, which were more than 900 people. The analysis highlights the importance of adopting indirect costs in economic estimations, and especially considering the economic loss with victims in studies with the presence of human lives in risk areas.

The lack of publications regarding official national data, both for direct and indirect costs, hindered our final cost estimation. Although there is a greater amount of data in the international literature, they could not be attributed to this research due to their value discrepancy. For example, in Brazil, the highway construction cost is of USD 0.84 million $/ \mathrm{km}$ [50] and in Spain, USD 6.74 million/ $/ \mathrm{km}$ [92].

Despite the difficulties in measuring direct and indirect costs, because of the variables involved in the landslide event, the research presents costs that can be applied in countries with economic characteristics similar to Brazil. The steps presented in the methodology can also be used for estimating costs in other countries using their local data.

\subsection{Vulnerability Assessment}

Through the proposed vulnerability assessment methodology, a total vulnerability map could be drawn, (Figure 7), according to the maps referring to body injuries, structural damages and functional disturbances.

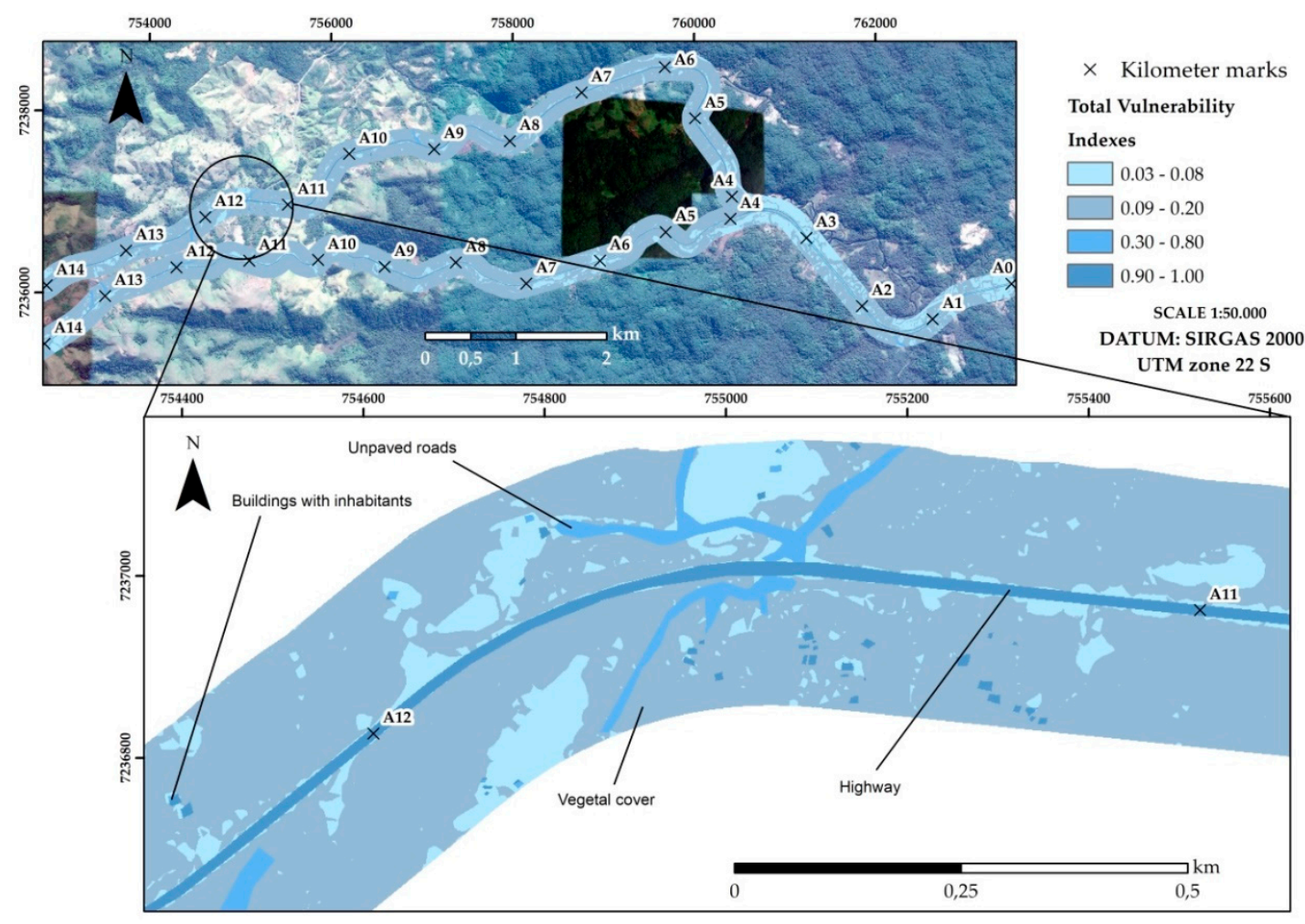

Figure 7. Total vulnerability map with distribution of indexes in function of the corporal damages, structural damages and functional perturbations.

In the map of body injuries and functional disturbances, the highway, infrastructures, and buildings with inhabitants, the selected areas were those that presented greater vulnerabilities because of the elevated possibility of victims in case of landslides. As for the structural damages map, besides 
the highway, some regions of the infrastructures and buildings, and some sections of the unpaved roads presented elevated vulnerability indexes, which mostly happen due to the declivity found where those elements are situated.

The vulnerability indexes were classified in four natural breaks, therefore making possible to group the data with lower variation, statistically establishing their spatial standards. The four classes are: (i) 0.03 to 0.08 , (ii) 0.09 to 0.20 , (iii) 0.30 to 0.80 , and (iv) 0.90 to 1.00 , represented in an ascending color scale according to their values.

Detailing the kilometer marks A11-A12 (towards Paraná) allows a better visualization of the indexes distribution, where the most vulnerable elements correspond to the buildings with inhabitants, the highway, the infrastructures and the unpaved roads, respectively (Figure 7).

Vulnerability assessment is extremely important in the process of assessing economic risk in the region of interest, as it has identified areas that are more vulnerable, allowing risk reduction strategies to be directed towards these regions, for example constructing retaining walls or reallocating local population.

The assessment also contributed to the increase of studies on the subject. From the vulnerability map, the next step is evaluating detailed knowledge of the local population with the possibility of suffering from landslide events and the training local population to know how to act in risk situations, because in Brazil the vulnerability is directly related to the lack of knowledge about the risks $[73,93]$.

\subsection{Susceptibility Assessment}

To evaluate susceptibility, a Safety Factor $\left(\mathrm{F}_{\mathrm{S}}\right)$ was initially modeled, allowing the identification of the susceptibility of a given area to be affected by translational landslides (Figure 8). The spatial model obtained values which were divided into class intervals ranging from $0 \%$ up to $50 \%$, meaning the probability of the occurrence of landslides.

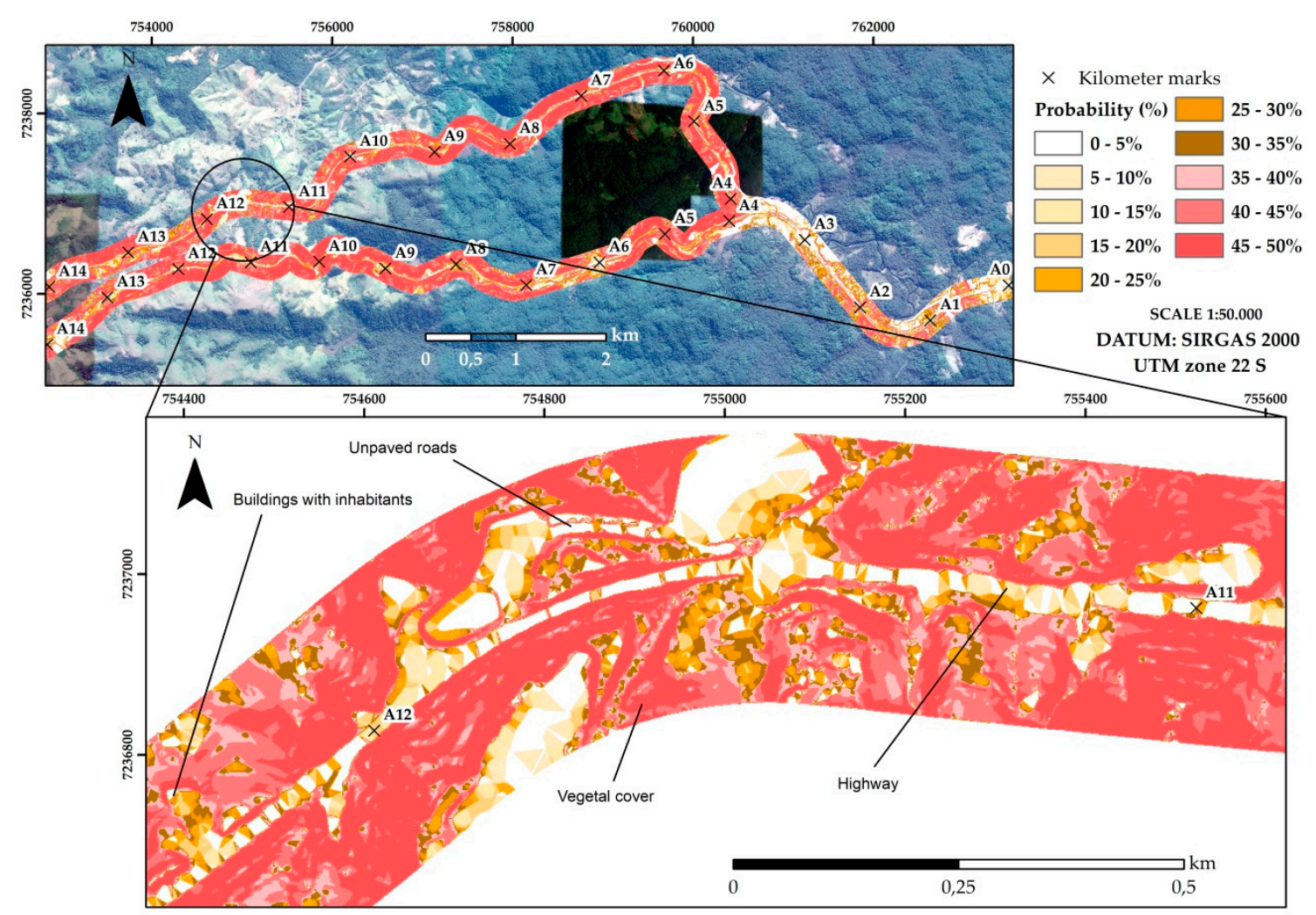

Figure 8. Probability map, developed from the reliability index, with identifications of the most susceptible areas to landslide occurrence. 
Although the method used [84] does not present an elevated accuracy because it only considered percentages of up to $50 \%$ of rupture probability, its distinction refers to the use of the analysis of the soil's physical parameters, without considering the multi-temporal analysis and the frequency of past events, allowing the evaluation in spite of the absence of prior landslide local data.

It is important to stress that the susceptibility assessment step here was carried out to apply the proposed methodologies in risk analysis. Susceptibility analyses have been developed with great detail in the Serra do Mar region [30,94]. For studies with data on the variations of soils mechanical parameters and past landslides, it is recommended the use of data mining and machine learning models because they allow the quantification of the uncertainties from the variability of the geotechnical parameters.

The susceptibility assessment was fundamental for applying the methodologies for measuring economic risk and vulnerability, allowing the identification of the most susceptible area to landslide occurrences, and it also enabled the creation of a risk model through the product between maps of cost, vulnerability and susceptibility.

\subsection{Risk Assessment}

The final risk model (Figure 9) was obtained through the product between the maps of landslide probability, vulnerability and total costs of the exposed elements of the region. It allowed the design of a tool that can be applied in risk management and decision making processes based on the concept of monetized risk.

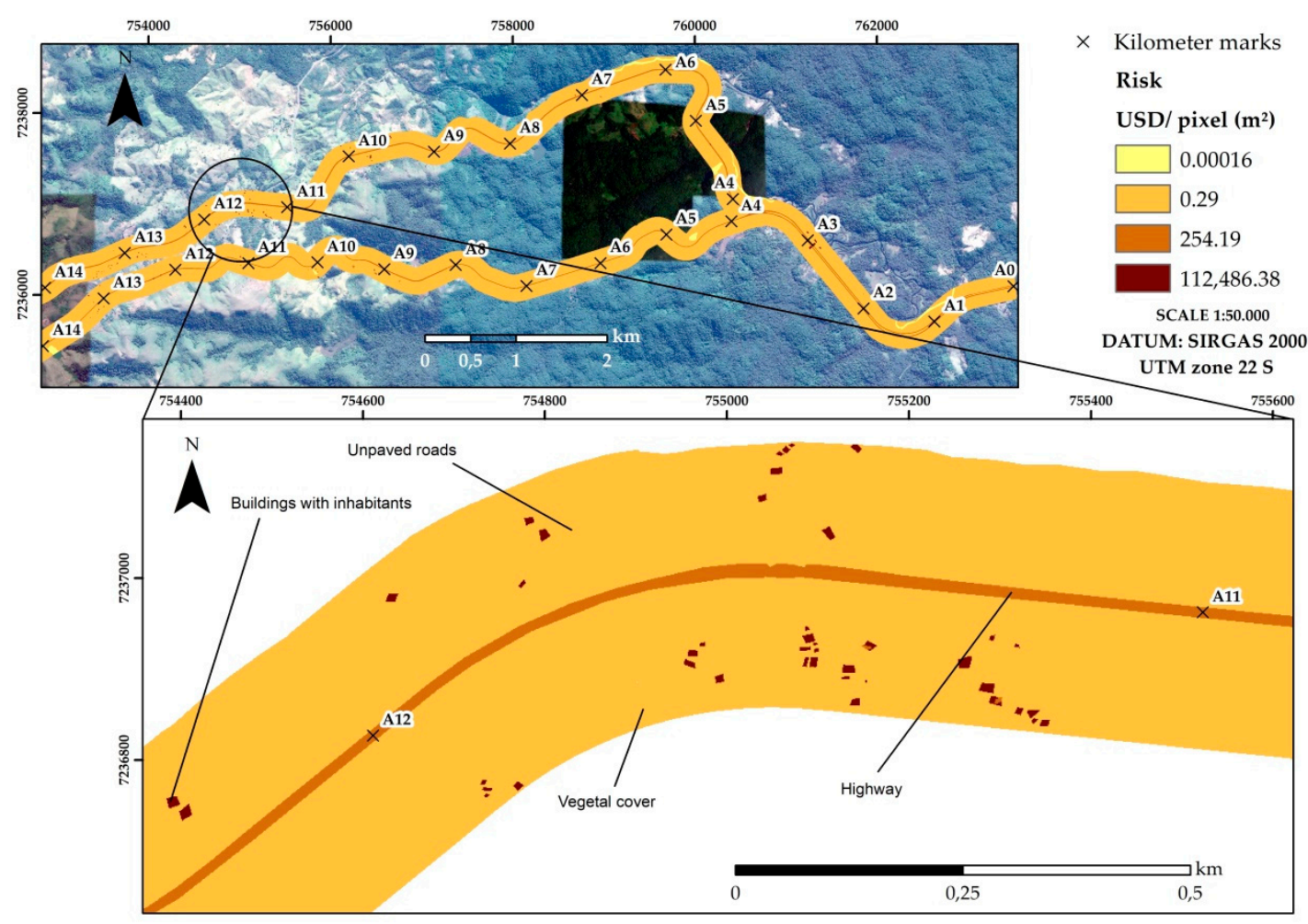

Figure 9. Economic risk map with kilometer mark details with areas of higher costs $\left(\mathrm{USD} / \mathrm{m}^{2}\right)$.

In the mapping of landslides economic risks, the kilometer marks A11-A12 (towards Paraná), were identified as the segment with greater economic risk inside the study area, characterized by the elevated presence of an urbanized portion (Figure 9), where the cost becomes preponderant in economic measurement and the risk mitigation efforts should be directed.

The maximum cost per pixel around USD 112 thousand $/ \mathrm{m}^{2}$ corresponds to the urbanized areas, which represent approximately $1 \%$ of the total studied area. On the other hand, the areas with lower 
costs are the vegetation cover and unpaved roads, which represent $95 \%$ of the total area, and they showed values below USD $0.29 / \mathrm{m}^{2}$.

With the purpose of validating the results found through the methodologies applied in the risk assessment, a comparative study was made on the landslide costs from other methodologies.

In Flanders-Belgium [95] it was performed a quantitative economic assessment of direct and indirect damages caused by landslides in a study area of $2910 \mathrm{~km}^{2}$, obtaining values around USD 3,390,322.11, which corresponds to USD 0.0011/ $\mathrm{m}^{2}$. In Spain [92], the risk assessment based on direct and indirect costs generated values of around USD $0.0034 / \mathrm{m}^{2}$. In Vernazza-Italy [14] an estimate was made on the economic losses caused by landslides, obtaining the maximum cost of USD $1.17 / \mathrm{m}^{2}$.

In every methodology presented, it was considered a return period of 1 year, different from this research, in which no return period was considered due to the lack of landslide history records. In none of the presented methodologies the indirect economic loss by victims was estimated, which was preponderant in this paper. Therefore, the maximum value of the risk (USD 112,486.38/ $\mathrm{m}^{2}$ ) obtained is different from the ones presented in the aforementioned studies.

On the other hand, the minimal risk value of USD $0.00016 / \mathrm{m}^{2}$ to USD $0.29 / \mathrm{m}^{2}$ agrees with the presented values by the previously mentioned methodologies. It should be stressed that the cost values can be different due to intrinsic economic features of each region and country, especially in comparison with Brazil, which is a developing country, different from the aforementioned European examples.

Therefore, to compare the results obtained with the national values, the total cost was compared based on the infrastructure, social, productive, and environmental sectors presented by the economic loss report of the disaster occurred in Rio de Janeiro [91], where seven cities were affected, with a total area of $3664.90 \mathrm{~km}^{2}$. The disaster cost USD 1.25 billion, resulting in a mean value of USD $0.34 / \mathrm{m}^{2}$, a value that is within the value interval obtained in the model without considering the economic loss with victims.

Although obtaining the cost $/ \mathrm{m}^{2}$ of other international risk models and the national mean cost $/ \mathrm{m}^{2}$ might govern a comparison with the results obtained from the research model, it should be noticed that each model has its own specificity. Therefore, the cost composition differs according to the parameters employed, and, in this model, the areas were mapped. In other words, each square meter presents a different value according to the element composition of the area.

Knowing the areas with greater economic risks can be of assistance in the prevention of landslides, an action that is usually seen as an expense and not as an investment [96].

In a next step, the present research enables a cost-benefit analysis of risk mitigation measures, by analyzing the cost $/ \mathrm{m}^{2}$ of an earth retaining structure to its useful life, with the cost of the risk $/ \mathrm{m}^{2}$ obtained from the economic risk through the methodologies presented herein. Consequently, the risk assessment in economic terms can be employed as a persuasion strategy to make the public bodies apply prevention measures, such as containment and stabilization works in regions of greater risks, avoiding that the measures only be taken after the landslide event already occurred.

\section{Conclusions}

This article presents the proposed methodologies for economic measurement of landslides and vulnerability assessment, aiming at applying those methods in economic risk analysis. The loss and damage mapping was performed through the total cost measurement by pixel $(1 \times 1 \mathrm{~m})$, composed of direct and indirect costs. The proposed methodology for measuring indirect costs encompassed several features, such as profitability losses for agricultural areas, losses generated by traffic jams caused by the highway interdiction during landslide situations, and the distinguishing factor which was analyzing economic losses with victims, not usually considered in cost estimations. Regarding direct costs, the composition encompassed the damages related to restoration or construction of the highways, infrastructures, unpaved roads, residential and commercial buildings, vegetal cover, and agricultural areas. The vulnerability was assessed and based on bodily injuries, structural damages, and on the functional disturbances of exposed elements, through the attribution of loss indexes ranging 
from 0.0 to 1.0 along the highway domain area. Landslide susceptibility assessment was undertaken with the purpose of obtaining the economic risk map of the study region, by the product between the maps of probability, total costs and vulnerability. The methodologies and tools here presented allow the procedures used to measure the economic risk to be applied in other regions, using local data, helping public bodies in decision making processes. To reduce landslide risks, said procedures facilitate the identification of areas in which mitigation efforts should be concentrated.

Author Contributions: Conceptualization, E.F.B., L.D.B.P. and A.C.M.K.; methodology, E.F.B.; formal analysis, E.F.B.; investigation, E.F.B.; writing—original draft, E.F.B., L.D.B.P. and A.C.M.K.; writing—review and editing, E.F.B., L.D.B.P. and A.C.M.K.; supervision, L.D.B.P. and A.C.M.K.

Funding: This research received no external funding.

Acknowledgments: The authors would like to thank the Federal University of Paraná (UFPR), the support of the Technological Development Resources-RDT, of the Concessionaire Arteris S.A., under the control of the National Agency of Ground Transportation-ANTT, for making possible the accomplishment of this research project.

Conflicts of Interest: The authors declare no conflict of interest.

\section{References}

1. Brabb, E.E. The world landslide problem. Episodes 1991, 14, 52-61. [CrossRef]

2. Schuster, R.L.; Highland, L.M. Socioeconomic Impacts of Landslides in the Western Hemisphere; United States Geological Survey: Reston, VA, USA, 2001; pp. 1-47. [CrossRef]

3. Fell, R. Landslide risk assessment and acceptable risk. Can. Geotech. J. 1994, 31, 261-272. [CrossRef]

4. Kim, H.G.; Lee, D.K.; Park, C. Assessing the cost of damage and effect of adaptation to landslides considering climate change. Sustainability 2018, 10, 1628. [CrossRef]

5. Mousavi, S.M.; Omidvar, B.; Ghazban, F.; Feyzi, R. Quantitative risk analysis for earthquake-induced landslides-Emamzadeh Ali, Iran. Eng. Geol. 2011, 122, 191-203. [CrossRef]

6. Varnes, D.J.; International Association of Engineering Geology; Commission on Landslides and Other Mass Movements on Slopes. Landslide hazard zonation: A review of principles and practice. In Natural Hazards; United Nations Economic, Scientificand Cultural Organization (UNESCO): Paris, France, 1984; pp. 1-63. ISBN 9231018957.

7. Crozier, M.J.; Glade, T. Landslide hazard and risk: Issues, concepts and approach. In Landslide Hazard and Risk; Glade, T., Anderson, M., Crozier, M.J., Eds.; John Wiley \& Sons Ltd.: Chichester, West Sussex, UK, 2012; pp. 1-40. ISBN 0471486639.

8. Zêzere, J.L.; Garcia, R.A.C.; Oliveira, S.C.; Reis, E. Probabilistic landslide risk analysis considering direct costs in the area north of Lisbon (Portugal). Geomorphology 2008, 94, 467-495. [CrossRef]

9. Michael-Leiba, M.; Baynes, F.; Scott, G.; Granger, K. Quantitative landslide risk assessment of Cairns, Australia. In Landslide Hazard and Risk; Glade, T., Anderson, M., Crozier, M.J., Eds.; John Wiley \& Sons Ltd.: Chichester, West Sussex, UK, 2012; pp. 621-642. ISBN 0471486639.

10. Remondo, J.; Bonachea, J.; Cendrero, A. A statistical approach to landslide risk modelling at basin scale: From landslide susceptibility to quantitative risk assessment. Landslides 2005, 2, 321-328. [CrossRef]

11. Brookshire, D.S.; Chang, S.E.; Cochrane, H.; Olson, R.A.; Rose, A.; Steenson, J. Direct and indirect economic losses from earthquake damage. Earthq. Spectra 1997, 13, 683-701. [CrossRef]

12. Hallegatte, $\mathrm{S}$. An adaptive regional input-output model and its application to the assessment of the economic cost of Katrina. Risk Anal. 2008, 28, 779-799. [CrossRef]

13. Spiker, E.C.; Gori, P. Mitigation strategy: A framework for loss reduction. Circular 2003, 1-64. [CrossRef]

14. Galve, J.P.; Cevasco, A.; Brandolini, P.; Piacentini, D.; Azañón, J.M.; Notti, D.; Soldati, M. Cost-based analysis of mitigation measures for shallow-landslide risk reduction strategies. Eng. Geol. 2016, 213, 142-157. [CrossRef]

15. Schuster, R.L.; Fleming, R.W. Economic losses and fatalities due to landslides. Environ. Eng. Geosci. 1986, 23, 11-28. [CrossRef]

16. Guthrie, R. Socio-Economic Significance-Canadian Technical Guidelines and Best Practices Related to Landslides: A National Initiative for Loss Reduction; Natural Resources Canada: Ottawa, ON, Canada, 2013; pp. 1-19. [CrossRef] 
17. Zêzere, J.L.; Oliveira, S.C.; Garcia, R.A.C.; Reis, E. Landslide risk analysis in the area north of Lisbon (Portugal): Evaluation of direct and indirect costs resulting from a motorway disruption by slope movements. Landslides 2007, 4, 123-136. [CrossRef]

18. Highland, L.M. Estimating Landslide Losses_Preliminary Results of a Seven-State Pilot Project; United States Geological Survey: Reston, VA, USA, 2006; pp. 1-11. [CrossRef]

19. Van Westen, C.J.; Van Asch, T.W.; Soeters, R. Landslide hazard and risk zonation-Why is it still so difficult? Bull. Eng. Geol. Environ. 2006, 65, 167-184. [CrossRef]

20. Sidle, R.C.; Ochiai, H. Landslides: Processes, prediction, and land use. Water Resour. Monogr. $2006,18$. [CrossRef]

21. Wong, H.N.; Ko, F.W. Landslide Risk Assessment: Application and Practice; Geotechnical Engineering Office: Homantin, Kowlonn, Hong Kong, 2006; pp. 1-280.

22. Remondo, J.; Bonachea, J.; Cendrero, A. Quantitative landslide risk assessment and mapping on the basis of recent occurrences. Geomorphology 2008, 94, 496-507. [CrossRef]

23. Sunuwar, L.; Karki, M.B.; Shrestha, D. A preliminary landslide risk assessment of road network in mountainous region of Nepal. In Landslide Risk Management; Hungr, O., Fell, R., Couture, R., Eberhardt, E., Eds.; Taylor \& Francis Group: London, UK, 2005; pp. 411-422. ISBN 041538043X.

24. Galve, J.P.; Cevasco, A.; Brandolini, P.; Soldati, M. Assessment of shallow landslide risk mitigation measures based on land use planning through probabilistic modelling. Landslides 2015, 12, 101-114. [CrossRef]

25. Lari, S.; Frattini, P.; Crosta, G.B. A probabilistic approach for landslide hazard analysis. Eng. Geol. 2014, 182, 3-14. [CrossRef]

26. Chen, W.; Pourghasemi, H.R.; Kornejady, A.; Xie, X. GIS-based landslide susceptibility evaluation using certainty factor and index of entropy ensembled with alternating decision tree models. In Natural Hazards GIS-Based Spatial Modeling Using Data Mining Techniques; Springer: Berlin/Heidelberg, Germany, 2018; pp. 225-251. [CrossRef]

27. Kornejady, A.; Ownegh, M.; Bahremand, A. Landslide susceptibility assessment using maximum entropy model with two different data sampling methods. Catena 2017, 152, 144-162. [CrossRef]

28. De Ploey, J.; Cruz, O. Landslides in the Serra do Mar, Brazil. Catena 1979, 6, 111-122. [CrossRef]

29. Seluchi, M.E.; Chou, S.C. Synoptic Patterns Associated with Landslide Events in the Serra do Mar, Brazil. Theor. Appl. Climatol. 2009, 98, 67-77. [CrossRef]

30. Nery, T.D.; Vieira, B.C. Susceptibility to shallow landslides in a drainage basin in the Serra do Mar, São Paulo, Brazil, predicted using the SINMAP mathematical model. Bull. Eng. Geol. Environ. 2015, 74, 369-378. [CrossRef]

31. Cerri, R.I.; Reis, F.A.G.V.; Gramani, M.F.; Rosolen, V.; Luvizotto, G.L.; do Carmo Giordano, L.; Gabelini, B.M. Assessment of landslide occurrences in Serra do Mar mountain range using kinematic analyses. Environ. Earth Sci. 2018, 77, 1-16. [CrossRef]

32. Cruz, O. Studies on the geomorphic processes of overland flow and mass movements in the brazilian geomorphology. Rev. Bras. Geociências 2018, 30, 504-507. [CrossRef]

33. Vieira, B.C.; Fernandes, N.F.; Augusto Filho, O.; Martins, T.D.; Montgomery, D.R. Assessing shallow landslide hazards using the TRIGRS and SHALSTAB models, Serra do Mar, Brazil. Environ. Earth Sci. 2018, 77, 1-15. [CrossRef]

34. Ichihara, S.M.; Guilhoto, J.J.M. The impact of economic growth on the highways in São Paulo: An application of input-output model combined with GIS. SSRN Electron. J. 2008, 1-35. [CrossRef]

35. State Planning and Management Secretariat of São Paulo. Integrated regional plan of basic sanitation for UGRHI-11. In Planning Tools' Strengthening Program of the Sanitation Sector Ribeira de Iguape and South Coast; Sanitation and Power Department: São Paulo, Brazil, 2010; pp. 1-136. (In Portuguese)

36. CBH-RB - Drainage Basin Committee of Ribeira de Iguape and South Coast. Situation Report of the Hydric Resources of the Managerial Unit No 11: Drainage Basin of Rio Ribeira de Iguape. Available online: http://www.sigrb.com.br/app/pdf/Rel_de_\%20Situacao_RB_\%202008.pdf (accessed on 29 April 2019). (In Portuguese).

37. Lima, A.P.S. Analysis of the Formation Processes of Sítio Capelinha-Establishment of a Microregional Context. Master's Thesis, The University of São Paulo, São Paulo, Brazil, 2005. (In Portuguese). [CrossRef]

38. Rodrigues, R. Geological and Geotechnical Characteristics that Affect the Stability of Colluvium Masses of SERRA de Cubatão-SP. Ph.D. Thesis, The University of São Paulo, São Paulo, Brazil, 1992. (In Portuguese). 
39. EMBRAPA. Brazilian System of Soil Classification; National Center of Soil Research: Rio de Janeiro, Brazil, 2006; ISBN 978-85-7035-198-2. (In Portuguese)

40. Sadowski, G.R. Tectonic of Serra de Cubatão-SP. Ph.D. Thesis, The University of São Paulo, São Paulo, Brazil, 1974. (In Portuguese). [CrossRef]

41. Lacerda, W.A. Stability of natural slopes along the tropical coast of Brazil. In Proceedings of the Symposium on Recent Developments in Soil and Pavement Mechanics, Rio de Janeiro, Brazil, 25-27 June 1997; pp. 17-39.

42. Faleiros, F.M.; Morais, S.M.; Costa, V.S. Geology and Mineral Resources of the Apiai Sheet SG.22-X-B-V; CPRM: São Paulo, Brazil, 2012. Available online: http://rigeo.cprm.gov.br/jspui/handle/doc/11366 (accessed on 29 April 2019). (In Portuguese)

43. Riedel, P.S.; Gomes, A.R.; Ferreira, M.V.; Sampaio Lopes, E.S.; Sturaro, J.R. Identification of landslide scars in the region of the Serra do Mar, São Paulo State, Brazil, using digital image processing and spatial analysis tools. GIScience Remote Sens. 2010, 47, 498-513. [CrossRef]

44. Wong, H.N.; Ho, K.K.S.; Chan, Y.C. Assessment of consequence of landslides. In Landslide Risk Assessment, 1st ed.; Routledge: London, UK, 1997; pp. 111-149. ISBN 9780203749524.

45. Glade, T. Vulnerability assessment in landslide risk analysis. Die Erde 2003, 134, 123-146.

46. DNIT-National Department of Transport Infrastructure. PNT-National Research of Traffic. Available online: http://servicos.dnit.gov.br/dadospnct/Pnt/2016 (accessed on 29 April 2019). (In Portuguese)

47. ESRI. ArcGIS 10.5; GIS Software; ESRI: New York, NY, USA, 2012.

48. Trevizolli, M.N.B. Model Proposal for Landslide Risk assessment Based on Pluviometric Event Scenarios: Application on a Slope of Serra do Mar in the PR/SP Section. Master's Thesis, The Federal University of Paraná, Curitiba, Brazil, 2018. (In Portuguese).

49. Guide, A. Project Management Body of Knowledge (Pmbok ${ }^{\circledR}$ Guide); Project Management Institute: Newtown Square, PA, USA, 2000; ISBN 1-880410-23-0.

50. DNIT-National Department of Transport Infrastructure. Average Managerial Costs. Available online: http://www.dnit.gov.br/custos-e-pagamentos/custo-medio-gerencial/ ANEXOIXCUSTOMDIOGERENCIALJULHO2017.pdf/view (accessed on 29 April 2019). (In Portuguese)

51. EMATER-Paranaense Company of Technical Assistance and Rural Extension. Trafficability Recovery Project of Unpaved Roads. Available online: http://www.agricultura.pr.gov.br/arquivos/File/nuconv/ Aditivos/Convenio_435_California_diesel/CALIFORNIA_TA_CV435_2013_RVI.pdf (accessed on 29 April 2019). (In Portuguese)

52. CBIC-Brazilian Chamber of the Construction Industry. Brazil Mean CUB. Available online: http://www. cbicdados.com.br/media/anexos/7.1_Sala_de_Imprensa_75.pdf (accessed on 29 April 2019). (In Portuguese).

53. Cui, P.; Lin, Y.M.; Chen, C. Destruction of vegetation due to geo-hazards and its environmental impacts in the Wenchuan earthquake areas. Ecol. Eng. 2012, 44, 61-69. [CrossRef]

54. Corrêa, R.S.; Ferreira, G. Recovery of Areas Degraded by Mining on the Cerrado-Guidebook for Revegetation; Universa: Brasília, Brazil, 2009. (In Portuguese)

55. Vieira, T.P. Estimation of the Necessary Investment for the Recomposition of the Forest Cover at the APPS of the Basin of Ribeirão Itaim in Taubaté-SP. Master's Thesis, The University of Taubaté, Taubaté, Brazil, 2008. (In Portuguese).

56. MAPA-Ministry of Agriculture, Farming, and Supply. Available online: https://www.defesa.agricultura. sp.gov.br/noticias/2018/ministerio-da-agricultura-aprova-smr-para-a-sigatoka-negra-no-vale-do-ribeira, 1218.html (accessed on 29 April 2019). (In Portuguese)

57. Cardoso, C.E.L. Production cost of Musa x Paradisiaca, L. Musaceae. Available online: https://www. agencia.cnptia.embrapa.br/Agencia40/AG01/arvore/AG01_21_41020068055.html (accessed on 29 April 2019). (In Portuguese).

58. Miller, T.R. Variations between countries in values of statistical life. J. Transp. Econ. Policy 2000, 34, 169-188.

59. Porter, K.A.; Asce, M. Life safety risk criteria in seismic decisions. In Acceptable Risk to Lifeline Systems form Natural Hazard Threats; Taylor, C.E., VanMarke, E., Eds.; Technical Council for Lifeline Earthquake Engineering, American Society of Civil Engineers: Reston, VA, USA, 2001; pp. 1-24. Available online: https://pdfs.semanticscholar.org/a26c/5b7161a9b1d542e25bbe581b94e6616834ea.pdf (accessed on 29 April 2019).

60. Carvalho, J.L. Quantification of Product Loss with Traffic Accidents: Preliminary Methodology and Evidences; Funenseg: Rio de Janeiro, Brazil, 2015; ISBN 978-85-7052-577-2. (In Portuguese) 
61. IBGE-Brazilian Institute of Geography and Statistics. PNADC/T—National Research by Quarterly Domicile Sampling. Available online: https://sidra.ibge.gov.br/pesquisa/pnadct/tabelas (accessed on 29 April 2019). (In Portuguese)

62. McMahon, K.; Dahdah, S. The True Cost of Road Crashes: Valuing Life and Cost of a Serious Injury; International Road Assessment Programme: Hampshire, UK, 2010.

63. IBGE-Brazilian Institute of Geography and Statistics. CEMPRE-Statistics of the Company Central Registration. Available online: https://www.ibge.gov.br/estatisticas/economicas/outras-estatisticaseconomicas/9016-estatisticas-do-cadastro-central-de-empresas.html?edicao=15403\&t=sobre (accessed on 29 April 2019). (In Portuguese)

64. IBGE-Brazilian Institute of Geography and Statistics. Complete Mortality Chart for Brazil—2016. In Brief Analysis of Mortality Evolution in Brazil; IBGE: Rio de Janeiro, Brazil, 2017.

65. Jayasooriya, S.A.C.S.; Bandara, Y.M.M.S. Measuring the economic costs of traffic congestion. In Proceedings of the 3rd International Moratuwa Engineering Research Conference, Moratuwa, Sri Lanka, 29-31 May 2017. [CrossRef]

66. DNIT-National Department of Transport Infrastructure. Guidebook of Traffic Studies. Publication IPR-723. Available online: http://www1.dnit.gov.br/arquivos_internet/ipr/ipr_new/manuais/manual_estudos_trafego. pdf (accessed on 29 April 2019). (In Portuguese)

67. Winfrey, R. Economic Analysis for Highways; International Textbook Co.: Scranton, PA, USA, 1969; pp. 1-923. ISBN 978-0700222445.

68. ANP-National Agency of Oil. Price Consultation System. Available online: https://preco.anp.gov.br/ (accessed on 29 April 2019). (In Portuguese)

69. Régis Bittencourt Highway, S.A. Annual Complete Financial Statements 2018. Available online: http: //ri.arteris.com.br/ptb/7319/667946.pdf (accessed on 29 April 2019). (In Portuguese).

70. Van Der Knaap, W.G.M. The vector to raster conversion: (mis)use in geographical information systems. Int. J. Geogr. Inf. Syst. 1992, 6, 159-170. [CrossRef]

71. Arnone, E.; Francipane, A.; Scarbaci, A.; Puglisi, C.; Noto, L.V. Effect of raster resolution and polygon-conversion algorithm on landslide susceptibility mapping. Environ. Model. Softw. 2016, 84, 467-481. [CrossRef]

72. Guillard-Gonçalves, C. Vulnerability Assessment and Landslide Risk Analysis: Application to the Loures Municipality, Portugal. Ph.D. Thesis, Universidade de Lisboa, Lisboa, Portugal, 2016. [CrossRef]

73. Leone, F. Characterization of "Natural" Catastrophic Vulnerabilities: Contribution to a Multirisk Geographic Assessment (Land Movements, Earthquakes, Tsunamis, Volcanic Eruptions, Cyclones). Geography; Paul Valéry University: Montpellier, France, 2007. (In French)

74. Uzielli, M.; Lacasse, S. Scenario-based probabilistic estimation of direct loss for geohazards. Georisk Assess. Manag. Risk Eng. Syst. Geohazards 2007, 1, 142-154. [CrossRef]

75. IBGE-Brazilian Institute of Geography and Statistics. Demographic Census 2010: Characteristics of the Population and Domiciles: Results of the Universe; IBGE: Rio de Janeiro, Brazil, 2011. (In Portuguese)

76. Finlay, P.J.; Fell, R. Landslides: Risk perception and acceptance. Can. Geotech. J. 1997, 34, 169-188. [CrossRef]

77. Leone, F.; Asté, J.-P.; Leroi, E. Vulnerability assessment of elements exposed to mass-movement: Working toward a better risk perception. Landslides-Glissements de Terrain Balkema Rotterdam 1996, 1, 263-270.

78. Silva, M.; Pereira, S. Assessment of physical vulnerability and potential losses of buildings due to shallow slides. Nat. Hazards 2014, 72, 1029-1050. [CrossRef]

79. Ortigão, J.A.R.; Sayão, A. Handbook of Slope Stabilisation; Springer: Berlin/Heidelberg, Germany, 2004.

80. Römer, W. Accordant summit heights, summit levels and the origin of the "upper denudation level" in the Serra do Mar (SE-Brazil, São Paulo): A study of hillslope forms and processes. Geomorphology 2008, 100, 312-327. [CrossRef]

81. Tabalipa, N. Geoenvironmental Mapping of the City of Pato Branco, Paraná, as Tool for Territorial and Environmental Planning. Ph.D. Thesis, University of Paraná, Curitiba, Brazil, 2008.

82. Fiori, A.P. Stability study of slopes in the area of Guaraqueçaba, Paraná. Bol. Paraná. Geociências 1995, 43, 25-40. (In Portuguese)

83. Nunes, F.G. Investigation of risk areas based on the geoenvironmental dynamics of the slopes of Serra do Mar, in Paraná. Bol. Paraná. Geociências 2013, 52, 97-114. [CrossRef] 
84. Carmignani, L.; Fiori, A. Basics of Soil and Rock Mechanics; Oficina de Textos: São Paulo, Brazil, 2015; ISBN 9788579751844. (In Portuguese)

85. Wolle, C.M.; Pedrosa, J.A.B. Transition horizons condition slope stabilization mechanisms in Serra do Mar. In Brazilian Convention of Engineering Geology; Brazilian Association of Engineering and Environmental Geology: Itapema, Brazil, 1981; pp. 121-135. (In Portuguese)

86. Acevedo, A.M.G. Geological-Geotechnical Simulation to Evaluate Slope Stability Based on Geoprocessing Techniques. Ph.D. Thesis, University of Paraná, Curitiba, Brazil, 2017. (In Portuguese).

87. Coy, Y.S.M. Susceptibility Assessment of the Slopes of a Section of BR-376, between $\mathrm{km} 658+820 \mathrm{~m}$ and 660+690 m, PR. Master's Thesis, University of Paraná, Curitiba, Brazil, 2015. (In Portuguese).

88. Spiegel, M.R. Statistics: Summary of the Theory 875 Problems Solved 619 Problems Proposed; Mc Graw-Hill do Brasil: São Paulo, Brazil, 1977. (In Portuguese)

89. Trindade, A.V.; Borges, A.L.; Teixeira, A.H.C.; Matos, A.P.; Ritzinger, C.H.S.P.; Almeida, C.O.; Costa, D.C.; Costa, E.L.; Alves, E.J.; Coelho, E.F.; et al. Banana Tree Cultivation; Borges, A.L., Souza, L.S., Eds.; Embrapa Mandioca e Fruticultura: Cruz das Almas, Brazil, 2004; pp. 1-279. ISBN 85-7158-010-3. (In Portuguese)

90. Rose, A.; Porter, K.; Dash, N.; Bouabid, J.; Huyck, C.; Whitehead, J.; Shaw, D.; Eguchi, R.; Taylor, C.; McLane, T.; et al. Benefit-cost analysis of FEMA hazard mitigation grants. Nat. Hazards Rev. 2007, 8, 97-111. [CrossRef]

91. Mundial, B. Assessment of Losses and Damages-Floods and Landslides at the Mountain Range Region of Rio de Janeiro. Report Drafted by the World Bank with the Support of the State Government of Rio de Janeiro. Brasília. 2012. Available online: http://documents.worldbank.org/curated/en/260891468222895493/ pdf/NonAsciiFileName0.pdf (accessed on 29 April 2019). (In Portuguese).

92. Bonachea Pico, J. Development, Application and Validation of Procedures and Models for the Assessment of Threats, Vulnerability and Risk Due to Geomorphological Processes. Ph.D. Thesis, University of Cantabria, Santander, Spain, 2006. (In Spanish).

93. Rosa, T.C.D.S.; Sathler, M.; Costa, M.; Mendonça, M.B.D.; Reginensi, C.; Souza, R.M.D. Risk associated with mass movement in the Boa Vista Hill (Vila Velha/Espírito Santo): From territory characterization to the need for public policies. Cad. Metrópole 2018, 20, 399-421. (In Portuguese) [CrossRef]

94. Vieira, B.C.; Fernandes, N.F.; Filho, O.A. Shallow landslide prediction in the Serra do Mar, São Paulo, Brazil. Nat. Hazards Earth Syst. Sci. 2010, 10, 1829-1837. [CrossRef]

95. Vranken, L.; Van Turnhout, P.; Van Den Eeckhaut, M.; Vandekerckhove, L.; Poesen, J. Economic valuation of landslide damage in hilly regions: A case study from Flanders, Belgium. Sci. Total Environ. 2013, 447, 323-336. [CrossRef] [PubMed]

96. Mora, S.; Keipi, K. Disaster risk management in development projects: Models and checklists. Bull. Eng. Geol. Environ. 2006, 65, 155-165. [CrossRef]

(C) 2019 by the authors. Licensee MDPI, Basel, Switzerland. This article is an open access article distributed under the terms and conditions of the Creative Commons Attribution (CC BY) license (http://creativecommons.org/licenses/by/4.0/). 